Kaygl, 19(II)/2020: 542-569. Araştırma Makalesi | Research Article

Makale Geliş | Received: 01.07.2020

Makale Kabul | Accepted: 23.08.2020

Yayın Tarihi | Publication Date: 15.09.2020

DOI: 10.20981/kaygi.790348

\title{
Yasin GÖKHAN
}

Doktora Öğrencisi | PhD Candidate Bursa Uludağ Üniversitesi, İlahiyat Fakültesi, Bursa, TR Bursa Uludag University, Faculty of Theology, Bursa, TR ORCID: 0000-0002-6289-0876 yasin.gokhan@hotmail.com

\section{Dine Eleştirel Yaklaşımlar Bağlamında Pozitivizmin Serencamı}

\section{$\ddot{O} z$}

Pozitivist paradigmaya göre metafizik inançlar temelsiz ve bilim dışıdır. Adeta peri masalından farksızdırlar. Ancak söz konusu peri masallarının dünyanın her tarafına serpiştirilmiş devasa büyüklükte sanat harikası tapınakları ve kütüphaneler dolusu yazılı külliyatları bulunmaktadır. Öyle ki eğer onları çekip almak mümkün olsa dünyadan, yeryüzünde insanlık namına şaheser kalmazdı dense abartı olmayacaktır. Ancak ne kadar ihtişamlı olursa olsunlar anlamlarını kaybetmișlerdir. Bütün bir insanlık tarihi koca bir yanılsamadan, kalıntıları da adeta "tanrıların türbeleri"nden ibarettir artık. Devasa fiziki yapılardan daha tehlike olan ise zihinlerde kalan devasa metafizik yapılardır ki, ivedilikle yıkılmaları ve yerine rasyonel yapıların inşası gerekmektedir. Bu çalışma, Aydınlanma paralelinde gelişen pozitivist rasyonalitenin serencamını ve pozitivizm gemisinin genel bir güzergahını, panoramik bir perspektifle ortaya koymayı amaçlamaktadır.

Anahtar Kelimeler: Akıl, Bilim, Aydınlanma, Din, Mitoloji, Pozitivizm.

\section{Fate of Positivism in the Context of Religious Critical Approaches}

\section{Abstract}

According to the pozitivist paradigm, metaphysical beliefs are baseless and unscientific. They are almost no different from the fairy tale. However, in the world of these fairy tales, there are gigantic and magnificent temples and libraries full of books. Moreover, these structures are so many that it will not be an exaggeration to say that even though it is possible to pull them out of the world, there would be no traces of the magnificent structures on earth. However, no matter how magnificent, unfortunately they have lost their meaning. A whole human history consists of a huge illusion and its ruins are the tombs of God. What is more dangerous than the gigantic structures are the giant metaphysical structures that remain in the minds that they need to be demolished immediately and rational structures to be built instead. This study aims to reveal the fate of the positivist rationality developed in parallel with the Enlightenment and a general route of the ship of positivism with a panoramic perspective.

Keywords: Mind, Science, Enlightenment, Religion, Mythology, Pozitivism. 


\section{Giriş}

Kant'1n Romalı şair Horatius'tan alarak “Aydınlanma Nedir?” makalesi ile “Aydınlanmanın sloganı” ilan ettiği "Sapere aude! Aklını kullanmaya cesaret et!” (Kant 1984: 213; Kant 1963: 3) mottosunda özetlenen Aydınlanma paradigması bilme cesaretini merkeze alarak, yegâne bilgi kaynağı olarak aklı ve yegâne ölçü olarak da insanı temel almaktadır. Metafizik düşünce yerine natüralistik düşünce esas alınır. Doğaüstü düşünce olarak telakki edilen metafizik ve dini inançlar, temelsiz ve bilim dışı bulunduğu için dışlanır. Pozitif akıl ve eleştiri öncesi döneme ait ilkel düşüncelerden ibarettirler. Her şey aklın süzgecinden geçip yeterince rasyonalize edildiğinde ve tüm irrasyonel unsurlardan arındırıldığında, dini ve metafizik düşünceler hepsi boş inançlar mezarlığına dönüşecektir. İnançlar nihayetinde belirsizlik kaygısı, ölüm korkusu vb. insani zaafları algılama, anlamlandırma ve teselli biçimleridir. Bilim imkanından yoksun ilkel insanın bireysel ve sosyal psikolojik savunma mekanizmalarıdır. Ancak bilimsel gelişmelerin sağladığı pozitif bilgiler 1şı̆̆ında, zan ve tahminden öte bir değerleri bulunmayan metafizik yanılsamalara artık gerek kalmamıştır.

Gözlem ve deneye dayalı bilimsel metodu temele alan pozitif akıl, neden/niçin sorusu yerine "nasıl” sorusunu merkeze almaktadır. Yüzünü olgu ve olayların nedenine değil nasıl gerçekleştiğine, metafizik yerine fiziğe dönerek, yürürlükteki mekanik, materyalist ve determinist doğa yasalarını keşfe yönelmiştir. Böylece, cevapları doğası gereği zanni ve spekülatif olmak durumunda bulunan metafizik geleneğin temel sorusu olan neden sorusu, gittikçe yerini somut realiteyi esas alan nasıl sorusuna devretmiştir.

\section{Aydınlanma ve Bilim Çă̆ı}

Pozitif düşünce yönteminin kendini bilim ve teknolojinin somut başarılarıyla özdeşleştirdiği Aydınlanma çağında insanın kendine ve aklına olan güveni artmıştır. Böylece, bilgi sektörünü tekelinde tutarak domine etmeye çalışan kilisenin indirgemeci ve ideolojik din yorumu ve metafizik şiddet pratikleri nedeniyle çatışma kaçınılmaz hale gelecektir. Bazı filozoflar akıl ve vahyin birbirini yadsıdığını düşünürken, bir kısmı ise 
iki tanrısal gerçeklik arasında çelişki olamayacağını düşünmekteydiler. Kilise ise aslında yalnızca gerçeği aramaya talip olmaktan başka niyetleri bulunmayan büyük entelektüel dehalara karşı tatmin edici cevaplar aramak ve kendi yorumunu eleştirel bir okumaya tabi tutmak yerine acımasız yöntemlerle eleştirileri susturmaya ve baskılamaya çalışmıştır. Oysa daha önce aynı kilise, Aristo fiziği ve metafiziği ile akabinde Newton fiziği ile uzlaşıma dayalı (Taslaman 2016: 12) uylaşımcı rasyonaliteyi uzun yıllar sürdürebilmişti. Ne yazık ki, bir tür güç zehirlenmesi yaşamakta olan kilisenin mutlakiyetçi ve uzlaşmaz tutumu, insanlık düşünce tarihinde büyük bir travmaya dönüşecek ve yüzyıllarca sürecek olan bir din-bilim çatışmasına neden olan kıvılcımı ateşleyecektir. Bunda elbette "Batı Medeniyetinin Ísa Mesih'ten sonra en etkin adamı" olan Pavlus'un Yeni Ahit tescilli bilgi anlayışı temel etkendir; “God'a karşı son derece saygısız gevezelik ve saçmalıklardan ibaret olan 'bilgi' dedikleri şeylerden uzak dur. Onun (bilginin) peşinden giden bazı insanlar imandan sapmışlardır." (Alatlı 2019: 94) Çünkü "Bilgi kibirlendirir, fakat sevgi binâ eder." (Baykan 1996: 37) Kilisenin dogmatik ve uzlaşmaz tutumu, aforoz ve engizisyonlarla iyice sertleşince, kanayan yarayı kangrene dönüştürmüş ve aslında birçoğu kilise mensubu ve son derece dindar olan bilim adamları için entelektüel savaştan başka seçenek kalmamıştır. O halde artık kilisenin sahte ilahları ve boş inançlarına karşı çıkmanın ve "tanrıların maskesi"ni düşürmenin zamanı gelmiş te geçmektedir. (Paden 2008: 29) Artık kilisenin oyunları deşifre edilmeli, hesap sandalyesine oturtulmalı ve yüzyıllardır insanlığa yaşattığı metafizik istismarın hesabı sorulmalıdır. Batı düşüncesindeki büyük kopuşun ve paradigmatik kırılmanın fotoğrafını başarılı bir şekilde resmetmesiyle büyük takdir toplayan Paul Hazard "Batı Düşüncesindeki Büyük Değişme” kitabında yaşanan sosyokültürel değişimin temel dinamiklerini çözümlemeye tabi tutmaktadır. Paul Hazard mevzu bahis kopuş ve çatışmanın nihai halini tasvir babında, ünlü bir yorumunda oldukça manidar ve çarpıcı şu unutulmaz tespiti yapmaktadır; "Aydınlanmanın amacı "Hristiyanlı̆̆l sanık sandalyesine koymak", hatta "yaşamın dinsel yorumunu” sonlandırmaktır." (Köktaş 2017: 144) 
Büyük reformasyon süreci, elbette sosyal dengeleri ve kültürel dinamikleri büyük oranda sarsmış ve kalıcı değişimlere neden olmuştur. Nihayetinde sürecin sonunda, "Medeniyetlerin temeli olan tanrlardan artık bütünüyle sır perdesi kaldırıldı; din, en iyimser yaklaşımla budalalık ve yanlış, en kötü ihtimalle korkunç bir baskı şekli” olarak görülmeye başlanmıştır. (Paden 2008: 30) Bu sürecin temel dinamiği olan rasyonalizmin temel karakteristiği, bilginin yegâne kaynağı olarak görülen pozitif akıl için gerekli özgürlük ortamı arayışıdır. Özgürlük için ise doğaüstü tekelinin kırılması ve yerine natüralistik düşüncenin esas alınması gereği ön görülmüştür. İnsanın alâmeti farîkası olan akla karşı müsamahasız tavrı nedeniyle kilise ve temsil ettiği her şeye karşı derin bir güvensizlik ve öfke birikmiştir. Söz konusu konjonktür gereği rasyonalist paradigma, varoluş mücadelesinin esası olarak benimsediği akla saygı ve bireysel düşünceye özgürlük gibi en temel insani hak talepleri için radikalleşmek ve marjinalleşmek zorunda bırakılmıştır adeta.

Artık geometri zihniyetinin hâkim olduğu bir çağa, her şeyin ölçülebildiği ve ölçülemeyenlerin dışlandığı bir döneme girmiş bulunmaktayız. Dolayısıyla "herşey mezura ile ölçülmelidir; herşey rakam ve ölçüye göre düzenlenmelidir." 'Sütten ağzı yanan yoğurdu üfleyerek yer' misali, artık her şey ölçülebilmelidir; insan boyunda(!) olmalıdır. Evler, sokaklar, bahçeler hep aynı büyüklükte olmalı, tek tip binalar gözleri yormamalı, sürprizler olmamalı. Ne pahasına olursa olsun hesaplı olmalı; "korkunç, sarsılmaz bir saplantıdır bu yeknesaklık merakı" diyenler olsa da plansız bir şehir düşünülemez artık. Ya nüfus, beş yıl sonra, 10 yıl sonra, yüzyıl sonra ne olacak? Hep gayri muntazam, kontrolsüz ve can sıkıcı şeyler şu bilinmezlikler; "İnsan bu sarhoşluktan uyanıp da katı gerçekle karşılaşınca bayă̆ı üzülüyor.” O halde, yeni hayal kırıklıkları ve üzüntüler yaşamamak için modern insan, mümkün ve muhtemel acı gerçeklerle henüz gelmeden yüzleşmeli ve kontrol altına almalıdır. İsa Mesih ve Kitabı Mukaddes de aklımızı şaşırtan -mezuraya gelmeyen- efsaneler içermektedir; onlar da akıl ve bilimin açık, net ve keskin sınırları içine çekilmek durumundadır. (Hazard 1973: 31-32) O halde, en iyi din doğal ya da rasyonel dindir. Doğala en yakın ya da en az bozulmuş din arayışları Aydınlanmanın temel dinamiklerinden biri olmuştur. Kilisenin 
tekelinde olmayan ve herkesin ilahi kitabı okuyup anlayabileceği ve her türlü ibadetini bireysel olarak yapabileceği bir din olarak, Aydınlanmanın rol model din arayışı için referans noktası İslam dini olmuştur. (Kalın 2019: 259) Nitekim ilk dönemlerde Protestanlar "Müslüman" olmakla, öykünmecilikle suçlanmıştır. Ancak kapılarındaki "Türk tehdidi” konjonktürü kadar, aynı zamanda, "ilerleme miti”nin güdülediği ideolojik tarih yazımı anlayışı nedeniyle objektif bir değerlendirme imkanı gerçekleşmemiştir. Gerçekleştiğinde ise ancak oldukça sınırlı sayıda hakkaniyetli araştırmacı tarafından cılız bir sesle yapılabilmiştir. (Mete 2014: 55) Bu nedenle, İncil'in Almanca ve diğer yerel dillere çevirisiyle başlayan Protestanlık ve dinde reform hareketlerini bir rasyonalizasyon hareketi olduğu kadar, aynı zamanda bir İslamizasyon ve İslami rasyonaliteye öykünme hareketi olarak da değerlendirmek mümkündür.

\section{Pozitivizmin Evreleri}

Her türlü bilişsel boşluk ve belirsizliğin mitoloji, büyü ve kilisece istismar edilmek suretiyle rasyonel ve bilimsel düşünceye yaşam hakkı tanınmadığını düşünen, büyük çoğunluğu da teolog olan kimi rasyonalist düşünürler, gittikçe naturalist ve materyalist bir çizgiye kayan rasyonalist paradigmaya yön vermişlerdir. Bir anda ortaya çıkan keşifsel ya da devrimsel bir aydınlanma şeklinde değil, evrimsel gelişim çizelgesinde belirli duraklarda güç toplanması, ileri adımların test edilip yeni açılımlar ile zenginleştirilmesi, kimi hatalardan ders çıkarılması suretiyle ilerleyen bir süreçtir. Bu rasyonalizasyon sürecinin gelişim evrelerini ve rasyonel dönüşüm piramidinin basamaklarını değerlendirmeye geçebiliriz.

\subsection{Deizm}

Dini yadsımanın bir ara formülü olarak da değerlendirilebilecek deizm, 17. Yüzyıl Fransa'sında ortaya çıkmıştır. Latince “deus"tan türetilmiş ve "yaradancılık” anlamına gelmektedir. (Çüçen 2012: 347) Tanrı'nın yaratıcılığını kabul etmekle beraber insan hayatına müdahale edebileceğini kabul etmezler. Öncelikle, doğayı ezeli kabul edenler ve doğayı tanrının yarattığını kabul edenler olmak üzere iki ana formu vardır. Ancak her 
iki yaklaşımda da Tanrı yarattıktan sonra pasiftir. İlginçtir ki, "tanrının pasifliği" tezi deizm ve Hristiyanlıkta da ortak görüştür. Aristoteles menşeli, "hareket etmeyen Ilk Muharrik"e (Aristoteles 1996:484) indirgenmiş Tanrı anlayışının farklı versiyonlarıdır dense yeridir. Evreni ve insanı eksiksiz bir şekilde yaratan Tanrı, bir tür istirahate çekilerek, kurduğu mükemmel sistemi izlemek istemektedir. Kendisine verilen yeterli donanımla insan da tıpkı diğer canlılar gibi kendi hayatını idame ettirebilir. Evrende bir düzen olduğunu, bu düzenin kaynağının da Tanrı olduğunu hatta bütün bu nedenlerle Tanrı'ya minnettar olmak gereğini de yadsımazlar. Ancak kilisenin insana dayattı̆̆ı türden bir dini yaşam, insan için onur kırıcıdır. Tanrı insandan kilisenin hizmetkarı olmak gibi, son derece onur kırıcı ve kısıtlayıcı bir yaşamı istemiş olamaz. Tanrı düzeni kurmuş ve bu düzeni sürdürmeyi akıl sahibi insana bırakmıştır, kiliseye değil. Mucizeler gibi bu rasyonel düzene aykırı ve doğaüstü yorumlara inanmayı yadsırlar. Zira bunlar rasyonaliteye olduğu kadar Tanrı'nın kendi kurduğu doğal düzene de aykırıdır. Muhtemelen kilisenin cahil kitleleri manipüle etmek için kurguladığı illüzyonik kimi mistifikasyonlardan başka bir şey değildir. Artık İsa’nın yolunu terk etmiş kilisenin tekelinden dini ve tanrıyı kurtarmak gerektiği gibi halisane bir niyet ve motivasyonla yola çıkmış bulunsalar da sonuç maalesef ne din için ne de deistler için beklendiği gibi gelişmiş görünmemektedir. Şöyle ki, Hegel deizmi tanrıyı aklın hakkında hiçbir şey bilemeyeceği bir konuma yerleştirmekle itham etmektedir; deizm yoluyla tanrı nihayetinde akı1 ile karşı karşıya getirilmiş, insana hiçbir fayda sağlayamayan bir konuma düşürülmüştür. Artık "o yüce varlık boş ve ölüdür”, pratik hayatta kullarının imdadına yetişemeyen, hiçbir fayda sağlayamayan yüce bir varlığın imajinatif bir tasavvurundan ibarettir sadece. Nihayetinde elimizde kalan, "muhafaza edebildiğimiz tek şey Tanrının yüce varlığının tasavvuru, tanımı ya da soyutlamasıdır- soyutlamanın boşluğu, öbür dünyanın boşluğu. Bu tamamen rasyonel teolojinin sonucudur." (Hegel 2016: 18-19)

Deizmin tek bir yorumu yoktur elbette, sayısız farklı yaklaşımların kendisini deist olarak nitelediği bilinmektedir. Ancak görünen odur ki, dini temsil ettiği iddia edilen ancak fitraten kabulü mümkün olmayan kimi inanç ve uygulamaları reddeden ve 
kendilerini deist olarak tanımlayan genel çoğunluğun itirazı Tanrı'ya değildir. Dar görüşlü olarak niteledikleri kilisenin baskıcı ve otoriter din yorumunadır. Kilisenin yaptığı gerçek anlamda dindarlık değil, bir tür dinidarlıktır. Dolayısıyla kilisenin sahte dinine başkaldırmakla asıl dindar aslında kendileridir. Tanrı kullarını başka kullara ya da kiliseye kul olmasın diye, yolunu kendi seçebilsin diye gerekli akli ve vicdani mekanizmalarla donatmıştır. Bireyin kendi aklını bir başkasının rehberliğine ihtiyaç duymaksızın kullanabilme cesareti ve özgürce yaşamı önündeki engel tanrı değil, kilisedir. Zaten İsa'nın kilisesi yoktu, dindar olmak için gerekli de görmemiştir. Kilisenin yaptığı, kendi kendini dayatmasından başka bir şey değildir. Nitekim Luther'in İncil'i Almancaya çevirmesiyle birlikte kiliseye olan bu bağımlılık ortadan kalkmıştır. İlginçtir ki, büyük Alman felsefesinin doğuşu; Kant, Hegel vb. büyük alman filozofların ortaya çıkışı; her birinin dini ve dünyayı yeniden yorumlayışının İncil çevirisinden sonraya denk gelişi tesadüf olmasa gerektir.

O halde, esası "dini tekelcilik" ve "ruhban sinıfi" uygulamasına dayanan kilise sisteminin şiddetle yadsındığı; tanrı ve kul arasındaki aracılık anlayışının affı mümkün olmayan yegâne günah/şirk olarak nitelendiği başka bir din örneğin -özgürlügü ve özerk bir birey olmayı inancın ön şartı sayan bir din- İslam söz konusu olduğunda, deizm sorunsalı taşıma ve öykünmeci bir sorun durumuna düşmekten kendini kurtarabilir mi sorusu, doğrusu kayda değer bir sorudur. Farklı kültürler, farklı dinler ve dolayısıyla tamamen farklı dinamikler söz konusu olduğu halde, sorunun gerçeklik değeri ve mantıksal statüsünün değişmeksizin kalması ve aynı şekilde ele alınması ne derece mümkündür?

Oysa günümüzde postmodernist düşünürler açıkça ortaya koymaktadır ki, aslında ne evrenselleştirilebilecek tek tip saf bir akıl; mutlak, nesnel ve evrensel bir rasyonalite söz konusudur ne de tek tip bir din! (Tüzer 2009: 149) Oysa, kültürlerin en temel karakteristiği, otantikliği değil midir? Nitekim her toplumun, aynı din ve rasyonaliteyi benimsediklerinde dahi kendi kültürel renkleri ve kodlarıyla yoğurarak özgün bir şekilde yeniden ürettikleri bilinçli tecrübelerimizle sürekli gözlemleyebildiğimiz bir gerçekliktir. (Hick 1963: 121) Dolayısıyla bütün farklı dinleri ve sayısız fraksiyonlarını 
din adı altında tek bir kümeye yerleştirmek, Batıya özgü kültür ögelerini ve Batı tipi rasyonaliteyi evrenselleştirmek ve evrensel bir ilke ya da reçete olarak dikte etmek ne realiteye ne de pozitif akla uygunluk arz etmektedir. Rasyonel bir tercih olmaktan ziyade aslında teolojik bir tutumdur. Ayrıca kitapsız ve peygambersiz bir din, din denilen sosyolojik olgunun doğasına da uygun düşmemektedir. Yanlış temsiller nedeniyle bir gerçekliği tamamen yadsımak ne derece mümkündür? Nitekim deizm süreci boyunca da deistlerin relativizme kapılarak sübjektif bir psikolojizme, nihayetinde nihilizme ve zamanla daha negatif durumlara sürüklenmekten kendilerini kurtaramadıkları pozitif bir olgu olarak, deist tezleri adeta yadsımaktadır.

\subsection{Evrimci Teoriler}

Evrim teorisinin felsefi ve teolojik sonuçları nedir? Evrim teorisi yaratılış düşüncesi ile mutlaka çelişmek ve çatışmak zorunda mıdır? Bunlar elbette önemli ve değerli sor/u/n/lar olmasına rağmen makalemiz açısından bahsi diğer bir konudur, ancak evrim üzerinden hesaplaşmanın yürütüldüğü bir din-bilim savaşının yaşanmakta olduğu da tarihi bir vakıadır. 19. Yüzyılda modern akıl ve pozitivist bilim ekolü açısından evrim teorisi, her platformda dine karşı konumlandırılmış, adeta dini düşünceye atılan en büyük gol olarak değerlendirilmiştir. Öyle ki, eğer bir şey evrimle izah edilebiliyorsa tüm dini iddialar boşa çıkarılmıştır ön kabulüne dayalı bir saldırı stratejisi nedeniyle olsa gerek, neredeyse bütün bilimsel teorilerin tek motivasyon kaynağına dönüşüvermiştir. (Taslaman 2016: 12) Türlerin Kökeni kitabında Darwin, her ne kadar “evrimsel gelişimi Yaratıcı'nın gerçekleştirdiği bir süreç olarak gördüğünü” açıkça ifade etmiş ise de bu durum, gerçekleşmekte olan paradigmatik değişimin tarihsel süreci etkileyememiştir. (Taslaman 2016: 118) Darwin'in kendisi dahi materyalist anlamda bir Darwinci olmadığını ilan etmiş bulunmasına rağmen, dönemin pozitivist rüzgarlarının önüne gelen her şeyi silip süpürmesi, değişim talebini tetikleyen gerilim ve dinamiklerin gücü hakkında fikir vermesi bakımından düşündürücüdür. Bu bağlamda, gerçekten haklıymış demekten kendimizi alamadığımız, "bilimsel kuramdan ya da paradigmadan 
diğerine geçişi mistik bir ihtida" (Tüzer 2009: 124) olarak değerlendiren Thomas Kuhn'un paradigmal değişimlerin kaçınılmazlığı tezini adeta doğrulamaktadır.

Ayrica Darwin'den daha önce "Hegel ve Comte [ve hatta Marx] gibi felsefelerinde "evrim” kavramını merkeze oturtan iki düşünür canlıların evrim geçirdiğini hiç düşünmemişlerdir." (Taslaman 2016: 110) Biyolojik anlamda canlıların değişim ve dönüşümü anlamında bir mana kastedilmeden uzun yıllar boyunca evrim teriminin sosyal ve kültürel bağlamda kullanılması, yalnızca düşünsel ve felsefi bir tekâmülün kastedilmiş olması da sanırım evrim teriminin yaşam hikayesi açısından ilginç bir anekdot olsa gerektir.

\subsubsection{Naturizm Teorisi}

Tanrı isimlerinin tabiat güçleriyle ifade ediliyor olmasından yola çıkan Friedrich Max Müller'e (1823-1900) göre, tabiat varlıkları kendilerine duyulan şükran ve insanın doğasında bulunan sonsuzluk duygusu nedeniyle sembolik değerler yüklenmek suretiyle önce kişiselleştirilmiş, sonra da tanrılaştırılmıştır. (Morris 2004: 152-154) Dolayısıyla din, aslında varlıklara, krallara ve kahramanlara duyulan şükranın ifadesinden ibarettir. Bilgelerin sözleri dışında gökten inen bir şey yoktur aslında; zamanla yüceltilerek mitolojik kalıplara sokulmuş ve adına da "din” denilmiştir. Sonraki nesiller, bu metaforik ve mecazi ifadeleri mutlak anlayarak kutsamış ve tanrılaştırmışlardır. Aslında bu insanlar "koca birer çocuktan başka bir şey değildirler." (Schopenhauer 2013:102) Örneğin eti, sütü, derisi vb. sağladığı çok yönlü faydalar nedeniyle ineğe duyulan hayranlık, önce nesli tükenmesin diye koruma ve kollamaya yönelik kutsama zamanla tapınmaya dönüş olmalıdır. Çünkü primitif zihniyet akıl ve mantık ile değil, duyular ve duygular ile kavramaktadır. Rasyonel ve analitik değil, mistik ve bütüncü bir evren anlayışı hakimdir. "Ne kadar çocuksu olursa olsun, bir din her zaman insan ruhunu tanrının varlığının içine yerleştirir; ve ne kadar mükemmellikten uzak ve çocuksu olursa olsun tanrı inancı insan ruhunun ulaşabileceği ve kavrayabileceği en yüksek mükemmellik idealini temsil eder." şeklinde iyimser bir yaklaşım sergileyen Müller, ilk dinlerin tektanrıcı olduğunu savlayan Alman ekolünü benimsemiştir. Tabiatın bölümleri 
olan küçük ve anlamsız parçalara tapınmayı ise dinin bozulmuş versiyonları olarak değerlendirmiştir. (Morris 2004: 152-153).

\subsubsection{Animizm Teorisi}

Primitif insan bütün doğa nesnelerinin her birinin birer ruhu olduğunu ve dolayısıyla her birinin canlı olduğunu varsaymaktadır. Animizm, dinin ilk nüvesinin, evrendeki her şeyin canlılığına duyulan inançtan kaynaklandığını savlayan teoridir. Temsilcileri Herbert Spencer (1820-1903), Edward Tylor (1832-1917) ve James Frazer'den (1854-1951) oluşan İngiliz ekolü'dür. Filozof Henry Aitken, öncü çalışmaları nedeniyle Spencer'i “evrimin peygamberi” olarak niteler. Darwin'den de önce evrimci ilerleme ve tekamül fikrinin kurucu tohumlarını ortaya atan ilk teorisyendir. Animizm ve natürizm denilen her iki akıma göre de insan, akıl ve mantık sahibi bir canlıdır. Fakat henüz yeterli bilgi ve kavramlara sahip olamadığı için yanılgılara düşmesi nedeniyle dini evreden kurtulamamıştır. Yani dinî inançlar, aslında birer mantık ve çıkarım hatasıdır. Zor zamanlarda atalarının ruhlarına sığınma ihtiyacı duyan insan aklı, öncelikle ruh fikrini, zamanla da ruh kavramını temele alan din fikrini geliştirmiştir. Atalar bedenen ölmüş olsalar da ruhları ölmemiş ve ruhlar panteonunda varlıklarını sürdürmektedir. O halde, özel teknikler ile ruh çağırmak neden mümkün olmasın? Ruh çağırma bilginlerinin, ruh çağırma tekniklerini ve ritüellerini geliştirmesi zamanla dine, ruhlar panteonu da tanrılar panteonuna dönüşmüştür. Dolayısıyla Spencer’a göre, “atalar tapımı her dinin kökenidir.” (Morris 2004: 159) Evrimsel olarak şöyle bir ilerleme şablonu ön görmektedir;

\section{- ATALAR RUHU $\rightarrow$ RUH ÇAĞIRMA $\rightarrow$ RUHLAR PANTEONU $\rightarrow$ TANRI}

Frazer de benzer şekilde, yine evrimci bir tablo ortaya koymaktadır. Sırayla önce en sübjektif evre olan büyü, sonra daha soyut ve nesnel olan din ve nihayetinde gelişim sürecini tamamlayarak rasyonel evreye ulaşıldığında ise bilim ortaya çıkmıştır;

$$
\bullet \text { BÜYÜ } \rightarrow \text { DİN } \rightarrow \text { BİLIM }
$$


İlkel insan büyü döneminde doğal yollarla güç yetiremediği olaylara bir takım düşünce gücü teknikleri olan büyü ile müdahale edebildiğini düşünerek teselli buluyordu. Yoksa ilke insan çift sürmek, ekmek yapmak vb. güç yetirebildiği gündelik işleri için hiçbir zaman büyüye başvurmuyordu. Sonra bir insani düşünce gücü varsaydığı büyünün de yetersiz kaldığı durumlarda, tabiatüstü güçlere sığınmaya ve onlardan yardım istemeye başladı. İşte “din” bu noktada ortaya çıkmıştır; insanın bittiği yerde, bir son çare ve sığınak olmuştur. Nihayetinde bir gerçeklik değeri ifade etmediği ve bir yanılsama olduğunun anlaşıldığı modern zamanlara gelindiğinde ise bilimsel düşünme aşamasına geçilmiştir. Frazer’a göre, “Tek gerçekçi düşünce biçimi, bilimsel düşünce biçimidir!" Diğer düşünme biçimlerinin ise düşünce hataları olmaktan başka epistemik bir değerleri yoktur. (Morris 2004: 165-172).

David Hume ise dinin primitif versiyonlarının çoktanrıcılık olarak başladığını, daha sonra gelişme göstererek tektanrıcılığa dönüştüğünü savlayanlardandır. O'na göre dinler, akıl kaynaklı değil, "yaşamın doğal belirsizliklerinde, gelecek korkusundan" fışkıran bir tür duygu patlamalarıdır. (Morris 2004: 228) Hayatı anlamlandırma, umut ve güven sağlama ve mutluluk arzusunu garantiye alma gibi işlevler dinin en temel fonksiyonudur. Oysa artık modern insanın böylesi sahte güvence ve tesellilere ihtiyacı yoktur. Acı da olsa kendi dışında bir gerçeklik olmadığı gerçeğiyle yüzleşmeyi ve hayallerin arkasına saklanmamayı öğrenmesi gerekmektedir. "Din, insan yaşamının “düzensizlik sergileyen manzarası"nın üstesinden gelme aracıdır." (Morris 2004: 227228) Ruh, cin, tanrı, melek, şeytan, büyü bunların hepsi henüz aklın olgunlaşmadığı zamanlara ait yanılsamalardır; ilkel insanın başvurduğu çocuksu ve büyülü araçlardır. "Sıradan bir çoktanrıcı, ...evrenin her parçasını tanrılaştırır. Böyle birinin kurduğu dizgeye göre, ay, güneş, yıldızlar hep tanrılardır..." (Hume 2016: 57) Fakat artık profan ve realist aklın hakim olduğu bilim çağında arkaik düşünce biçimleri gerilerde kalmıştır. Artık insandan ve pozitif akıldan öte bir güç aramak anlamsızdır. Eğer bir tanrı söz konusu olacak ise o ancak akıl olabilir. Aydınlanma bir nevi aklı tanrılaştırmıştır; artık tanrı logostur, din ise hümanizmdir. 


\subsubsection{Totemizm Teorisi}

Hakkını vermek gerekirse Freud oldukça inovatif bir şekilde, kendi özümüzden yola çıkar; bebeğin gelişim tablosunu toplum ve insanlığın kültür tarihine de uygular. Bebeğin büyümesi nasıl aşamalı bir düzen üzere ise aslında toplumsal ve kültürel gelişim tablosu da aynı şekildedir; basitten gelişmişliğe doğru evrilerek ilerlemektedir. Düşüncenin arkaik olarak en alt basamağı olan 'büyüsel dönem'den -bebeklik dönemikendine güvenli limanlar aradığı büyüme ve gelişme dönemi olan 'din dönemi'ne çocukluk dönemi- ve nihayetinde kendi aklını kullanmaya başladığ 1 'bilim dönemi'ne olgunluk dönemi- ulaşıncaya kadar geçerli olan bir gelişim tablosu söz konudur. (Freud 1999: 148-154) Bu gelişim tablosunu mukayeseli bir şekilde görselleştirmek mümkün olursa, teorinin orijinalitesi kendini daha iyi gösterecektir;

Çocuk ve Toplum açısından Gelişim Evreleri:

Bireysel/Biyolojik

1) Narsizm (ÖZSEVİCILİK) dönemi:

2) Anne-babaya BAĞLILIK dönemi:

3) Olgunluk (NESNELLIK) dönemi:
Toplumsal/Kültürel

BÜYÜSEL DÖNEM

DİNSEL DÖNEM

BİLIMSEL DÖNEM

Freud'a göre, dini duygunun çekirdeğinde anne-babaya karşı duyulan korku ve suçluluk duygusu yatmaktadır. Din, suçluluk duygusunun bastırılmasından kaynaklanan bir toplumsal Ödip kompleksidir, büyümek için aşılması gereken zorunlu ve faydalı bir ara dönemdir. Doğal gelişim süreci ile aşılamadığı zaman ise tedavi edilmesi zorunlu bir nevrozdur. (Freud 2014: 200-201) Dolayisiyla din, babanın ya da toplumun gücü karşısında duyulan korku, bastırılmış arzu ve ihtirasların bir yansıması ve bilinçaltının dişavurumudur. Özetle "Freud, dinsel tutumun (hatta evrenle "bir olma" şeklindeki basit mistik hissiyatın) özde çocuksu çaresizlik hissinden kaynaklandığını öne sürer." (Morris 2004: 259-260) Hakeza sadece çocuksu bulmakla da kalmaz, "aynı zamanda dinin tehlikeli olduğunu ileri sürer; öyle ki, din kötü insan kurumlarını kutsar; eleştirel düşünceyi yasaklayarak aklın yoksullaştırllmasına yol açar; ahlâki normları dinsel 
öğretilere bă̆layarak ahlâkı oldukça zayıf temeller üzerine yerleştirir." Nihayetinde, “insan mutluluğu, özgürlük ve gerçeğin din tarafindan tehdit edildiği”"ni düşünmektedir. Kendisini de bu noktada, insanlığı karanlıklardan aydınlığa çıkaran öncülerden biri olarak görmektedir. (Morris 2004: 263)

Freud'un anne-babaya bağl1lı̆̆ın nedenini ödenmesi mümkün olmayan emeğe, benzeri olmayan sevgiye, eşsiz iyiliklere, tarifsiz fedakarlıklara ve büyüleyici yüceliklere değil de korku, suçluluk duygusu vb. anne-baba denince akla en son gelebilecek enderiyattan hususlara bağlaması birçok yönden sorunsaldır. "Freud'un panseksüelizmi”, başta kendi öğrencileri olmak üzere, birçok bilim adamı tarafından yanlışlanmıştır. (Morris 2004: 266) Tüm orijinalitesine rağmen teori bu noktada realiteden tamamen kopmaktadır. Oysa kişinin anne-babasına sevgi ve muhabbet duymasından daha doğal ve reel ne olabilir şu hayatta? Hakeza, anne-baba da dahil olmak üzere hayatımızı çepeçevre kuşatan sayısız güzelliklerin nedeni olduğu düşünülen güce karşı minnettarlık duyulmasından daha rasyonel ne olabilir? Aslında sanıldığının aksine peygamberler hiç de idealist değildir, bilakis son derece realisttir. Çünkü realite etik ve teistiktir. Aksi halde, egosantrik bir etik üzerine ne düzen kurmak ne de düzen olmaksızın toplumsal yaşam sürdürmek mümkündür. (Hick 1963: 82) Böylesi bir deha için, kendi sübjektif tecrübesine aykırı olsa dahi, anne-baba olgusuna dair nesnel ve objektif realiteyi gözlemleyip çözümleyebilmesi hiç de zor olmasa gerektir. Değil elbette. Ancak ne yazık ki, bu defa da pozitivizm kilisesinin dogmaları özgür düşünceye imkân tanımamaktadır.

\subsubsection{Yansitma Teorisi}

Feurbach'a göre din, insani yansıtmalardır. Tanrı saflaştırılmış, nesnelleştirilmiş ve idealize edilmiş insan doğasından başka bir şey değildir. Tüm uyumsuzluklardan arındırılmış bir öz bilinç idealidir. İnsanın neye ihtiyacı varsa, o nihai arzusu yani Tanrı'sı olur; “Yaşam ne kadar boşsa Tanrı o kadar dolu ve zengindir. ....Yalnızca yoksul bir insanın zengin bir tanrısı vardır. Tanrı bir tek istek hissinden çıkar; insan neyin ihtiyacını duyuyorsa... o Tanrı'dır." (Morris 2004: 40-41) 
Kendisini dışa vurma ve nesnelleştirme yoluyla tanıması, insan doğasının bir özelliğidir. Kutsal, aslında insanın vizyonu ve ufkudur. Bireyin ufku ne ise tanrısı odur! Xenophanes'in ünlü teşbihiyle ifade edecek olursak; eğer hayvanlar kendi tanrılarını resmedebilecek olsalardı mutlaka kendi suretlerinde; atlar at, öküzler ise öküz şeklinde çizerlerdi. (Şimşek 2015:70) Kanıksadığımız için pek fark edemesek de, aslında insanlar için de durum farklı değildir. Belki de tanrı insanları kendi suretinde değil, insanlar tanrıyı kendi suretlerinde yaratmıştır. Eğer kuşların dini olsaydı, tanrıları kesinlikle kanatlı olurdu diyen Feurbach’a göre, din bizim düşümüzdür, doğamızın bir aynasıdır. Din aslında arzularımız, özlemlerimiz ve korkularımızın dinleştirilmiş halinden başka bir şey değildir! Kendi iç dünyasındaki tahayyüllerini dış dünyada sanki varmış ve gerçekmiş gibi dışsallaştırma ve inanma yetisine sahip yegâne varlık insandır. (Woods \& Grant 2018: 59).

Aslında her teorinin dine yönelik eleştirdiği hususlar, ilahi özden sapması muhtemel bir dini yorumun deşifresi olabilirliği bakımından kayda değerdir. Dekonstrüktif bir okumayla, tersinden eleştirel tavsiyeler ve çözüm önerileri olarak da değerlendirmek mümkündür. Şöyle ki, kutsanan gelenek önce statikleşip zamanla sorgulanamazlık zırhına bürününce, artık o aşamadan sonra özgürlügün teminatı olması gereken kutsal, köleleştirici bir yapıya dönüşsebilmektedir. Kur'an bu durumu "atalar dini” (Bakara, 2/170) olarak nitelemektedir ki, hayatın ve toplumun dinamik yapısına aykırılık arz etmektedir. Dolayısıyla topluma yön verecek büyük zekalara ayak bağı olmaktadır. Tekâmül ve ilerlemenin motivasyonu olması gereken kutsal değerler, gözle görünmeyen ama dokunanı yakan ateşten kafesler misali bir kutsal pranga olarak yaşam dinamiğine aykırılık arz etmeye başlamaktadır. İnsan psikolojisinin zaafından kaynaklanan, bir tür yüceltme oyunu olan bu yanılsama, aslında dinin de putlaştırma ve şirk olarak yadsıdığı, insani yorumların kutsanmasından; insani olanın kutsal özün aslını örtmesinden kaynaklanmaktadır. Ancak krizden tek çıkış yolu, kutsal özü de insani algı seviyesine indirgemek olmamalıdır elbette. Çünkü bu da daha vahim bir hata olacaktır; bir üst kategoriyi alt kategoriye eşitlemek suretiyle düşülen "kategori hatası" olacaktır. (Kalın 2020: 46) Aslında kutsal özü insani öze açınlayan ama indirgeyici olmayan, 
arındırıcı ve eleştirel bir akılla, sürekli orijinal olanın safiyetini korumaya dönük bir koruyucu hekimlik faaliyeti, rasyonalitenin en temel fonksiyonlarından biri değil midir? Tıpkı bedenimizdeki herhangi bir organı hastalandı diye kesip atmadığımız gibi, sürekli tedavi ve hastalıklardan korunma yollarını aradığımız gibi.

\subsubsection{Toplumun Duvara Yansıyan Silueti Olarak Tanrı}

Durkheim'e göre, dini duygu aslında sosyal duygunun kutsanmasından ibarettir. Din, toplum ve tabiatın doğal bir sonucudur. Toplumsal hayat bizatihi dinîdir. Toplumun ötesinde ayrıca din diye bir gerçeklik söz konusu değildir. Var olan tüm kutsallık, toplumun ortak kurallarının ta kendisidir. Din, toplumsal kuralların içselleştirilmesini sağlamak amacıyla yapılan bir yüceltme ve kişiselleştirme faaliyetinin sonucu ortaya çıkan sosyolojik bir fenomendir. Tanrı, toplumun duvara yansıyan bir siluetidir. Toplum neyse tanrı odur ve hakeza tanr1 ne ise toplum odur. Dinler aras1 farklar, aslında toplumlararası farklardan başka bir şey değildir. Toplum bizde kalıcı şekilde gerçekleşen bir olgudur. Çünkü bir toplum, kutsal açlığın doyumu için ruhlara aktarılması gereken ne varsa onu sunmak zorundadır. Bireyi topluma bağlayan bu sosyal duygu, dini duygunun esası ve kaynağıdır. O halde, din aslında, toplumun kendi bütünlük ve birlik bilincine varmasıdır. Dini ritüeller, toplumun bir araya gelerek yüce ideallerini kutsamasıdır. Gelecek nesiller için bir tür uygulamalı aktarım modelleridir. Okullarda rasyonel yolla verilen toplumsal ilkelerin, kutsal yoluyla coşku yüklü, sade ve somut simgeler şekline dönüştürülerek okul dışı kitlelere sunulmasıdır. Zira toplum dediğimiz yapı, oldukça dinamik ve kozmopolit bir yapıdır. Dolayısıyla toplumsal değerlerin okulda öğretilip bırakılması düşünülemez, bir paket program haline getirilerek, inanç cümleleri sadeliği ve dozajında sürekli hatırlatılması gerekmektedir. $\mathrm{O}$ halde, her toplumun mutlaka bir dini olmas1 gerekir. Nitekim tarihte dinsiz bir topluma rastlanmamasının nedeni de budur. Her toplum mutlaka bir din yaratır, dahası yaratmak zorundadır. Dinsiz bir toplum var olamaz; birlik ve beraberliğini sürdüremez, ortak ideallerini muhafaza edemez. Çünkü din, toplumsal yaşamı düzenleyen toplumsal sözleşmenin ve ideallerin ete kemiğe bürünmüş, yazılı olmayan anayasasından başka bir 
şey değildir. Toplumsal değerlerin bir projeksiyonu, toplumların vizyonu ve manifestosudur. Totemizm, yalnızca bir dinden ibaret görülemez. Aslında totemizm hem ilk din hem de ilk toplum modeli; ilk toplumsal sözleşme örneğidir. Animizm, natürizm gibi teorilerin hepsi bireyci temelde açıklamalar sunduğu için yetersizdir. Oysa açıkça görülmektedir ki, din sosyolojik bir yapı ve sosyokültürel bir kurumdur. Dinin kaynağı olarak toplumu görmesi nedeniyle Durkheim, söz konusu toplumsal realiteyi esas alan tek teori olması nedeniyle Totemizm teorisini benimsemiştir. (Morris 2004: 194-198) Schopenhauer da "din kalabalıkların metafiziğidir" ifadesiyle bu sava katılmaktadır. (Schopenhauer 2013: 16-17)

Sonuç olarak Durkheim'a göre, dinin aslında bir gerçeklik değeri yoktur, tamamen bir yanılsamadan ibarettir! Tarihsel konjonktürün determine ettiği, sosyal ve kültürel ihtiyaçlara bağlı olarak sürekli değişen bir tür kızıl elmadır, idealler demetidir. Ancak ne yazık ki, Durkheim tarafından din olarak baz alınan, argüman olarak sunulan dinî inançlar, örnek olarak seçilen ritüeller ve semboller hepsi Hıristiyanlık ve Yahudilik dinlerine aittir. Örneğin Hıristiyanlıktaki ekmek şarap ayini ile totem yeme ayini arasında gerçekten de fark bulunmamaktadır. Ancak bütün dinlerin aynı potada eritilmesi ne kadar nesnel ve bilimsel bir yaklaşımdır, realiteye ne kadar uygun düşmektedir? Oysa "din” değil, tarihsel "dinler" ve hatta dönemsel olarak farklı temsilleri söz konusudur. (Sharpe 1983: 78) Aslında Durkheim, peygamberlerin sürgünler, hicretler ve ölümler pahasına yürüttükleri mücadelelerini ve dinlerin varlık nedeni olan toplumsal muhalefet boyutunu tamamen ihmal ederek, kendi öznel tarihsel koşulları gereği, bir tür toplumsal asimilasyon nesnesine dönüşmüş belirli bir dinin belirli bir tarihsel kesitini genelleme yoluna giderek evrensel ilke haline getirmektedir. Bununla da kalmayıp canlı ve organik bir bütün olan tarih, toplum ve kültürü, Nietzsche perspektifiyle deşifre edecek olursak; bütün dinamikliği, akışkanlığı ve olumsallığına rağmen oluş dünyasının senfonik bütünlüğüne ve müzikalitesine aykırı bir inorganik, statik ve mekanik bir hakikat anlayışı (Aydın 1984: 82-83) temelinde ideolojik bir indirgemeye tabi tutmaktadir. 


\subsubsection{Sosyal Evrim Karşısında "Yabancılaşma" Olarak Din}

Marx'a göre din, sözde kozmik hakikat öğretileri içerisine kadim sosyal tabakalaşmayı kodlayarak, ezilen halkları kendi politik değerlerinin esaretinde tutmak için toplumu büyüleme ve uyuşturma aracıdır. Egemen sınıfın sahte otoritesi ve emperyalizmin meşrulaştırma aracıdır. Her zaman güçlünün (patron) yanında, zayıfın (işçi) karşısındadır. Üstelik zalimin karşısında mazlumun yanında retoriğiyle, kuzu postuna bürünmüş kurt taktiğiyle, kişiyi kendi özüne yabancılaştırıp kendi haklarına düşman k1larak yapmaktadır bunu. Sosyal sorunlara, hayali ve kandırmaca bir çözümdür. Haksızlıklarla yüzleşme ve mücadele yerine, bir tür kaçış, bir sığınaktır. Marx'ın ünlü ifadesiyle din, “kalpsiz bir dünyanın kalbidir.” Ancak sahte bir kalptir! Gerçekte ise "halkların afyonudur." (Kurt 2012: 79) Katlanılamaz acı ve 1stırapların, çekilen çilelerin teselli ve telafisi için hayali bir öteki dünya ütopyası, sömürünün devamı için kurbanları teskin edecek etkili bir uyuşturucu ve "tahakküm araçları" demetidir. (Morris 2004: 514-519) Emeğinin karşılığını isteyen işçiye patronun vadeyi ölüm sonrasına yani sonsuza dek ötelemesidir. Hayali bir tanrıyı yanına alan patronun işçilerine sınırsızca karşılıksız cennet çeki yazabilmesi imkanıdır. O halde, insanların hayali ve yanılsamaya dayalı mutluluğu demek olan dinin derhal ortadan kaldırılmasını istemek, aslında halkın gerçek mutluluğunu istemekten başka bir şey değildir. Filozofun görevi bireyi ve toplumu sadece bilgilendirmek değil, toplumu dönüştürmektir. Çünkü birey, toplumdan bağımsız ve müstakil fenomen olamaz, "toplumsal bir özdür" nihayetinde. Marx'ın sadece din değil kapitalizmi de içine alacak şekilde genişlettiği alinasyon/yabancılaşma eleştirileri gerçekten kayda değerdir; "Kapitalizm öncesi toplumların en belirgin özelliklerinden biri “dinsel yabancılaşma” iken kapitalizmde esas olan "iktisadi yabancılaşma” dır." Aslında her iki yabancılaşma formunun nedeni de aynıdır; insanın kendi el emeği ve göz nuru olan ürünlerin egemeni olması gerekirken esiri ve bağımlısı olma durumuna düşürülmesidir; "Dinde, insan kendi kafasından yarattığl şeyin (Tanrının) esiri olur; kapitalizmde ise, kendi eliyle yarattı̆̆ şeyin (metanın, sermayenin). Dinde, ideolojik fetişizm varken, kapitalizmde meta fetişizmi vardır." Dolayısıla, fenomenler farklı olsa da 
manipülasyon şekli aynıdır; "Nasıl ki dinde insan, kendi beyninin ürünü olan şeylerin egemenliği altına girmişse, kapitalist üretimde de, insanoğlu, kendi elinin ürünü olan şeylerin hükmü altına girer." (Orkunoğlu 2014: 60)

Vahşi kapitalizmin en acımasız dönemlerinde, haklı olanın değil güçlü olanın yanında saf tutan Katolik kilisesine karşı haklı isyanı ile kanayan vicdanların temsilcisi olarak Marx, takdire şayan bir duyarlılık sergilemiştir. Sanayi Devrimi sürecindeki insanlık dışı işçi hakları ihlalleri ve siyahların köleleştirilmesi vb. süreçte Katolik kilisenin savunulması mümkün olmayan din dışı pratiklerini mutlaklaştırıp evrenselleştirerek, yaşanan yanlış temsilin bireysel ve tarihsel faturasını, söz konusu vahşet pratiklerini kesin bir dille lanetlediği için çarmıha gerilen Hz. İsa'ya ve kendisiyle aynı vicdani duruşu benimseyen diğer dünya dinlerine dahi kesmekte sakınca görmemesi, söz konusu vicdani duyarlılık ile bağdaşmayan bir tutum olsa gerektir.

\subsection{Pozitivizm}

Pozitivizmin kurucu babası kabul edilen Auguste Comte'e göre, pozitivizmin esası "ucu kapalı bir evrim” anlayışıdır; yani insanlığın düşünsel gelişsimi teolojik aşama, metafizik aşama, üçüncü ve sonuncu evre olan pozitivist aşamadır. Artık daha ötesi yoktur. İnsanlığın gelişim çizgisi burada bitmektedir. (Taslaman 2016: 110) Artık deney ve gözlem konusu olmayan dini ve metafizik konular hakkında konuşamayı. Konuşsak da bunlar metafizik gevezelik ve zevzeklikten öteye geçmez. Metafizik ve dini düşüncenin rasyonalitenin hâkim olduğu modern dünyanın çağdaş sorunlarına karş1 çözüm üretemediği görülmektedir. O halde fonksiyonlarını tamamlamış geleneksel bilgi unsurlarını günümüzde halen devam ettirmenin anlamı yoktur. Geleneksel dönemlerdeki kültürel açlığa ve sosyal adaletsizliğe bir şekilde çözüm üretmiş olabilirler. Ancak modern ekonomilere dönük cevap üretmesini beklemek beyhûdedir. Çağdaş sorunlara, teknolojik yaşam koşullarına, metropol hayatına ve sanal dünyaya dair bir cevapları ve söyleyecek sözleri yoktur. Artık klasik din ve mezhep tartışmaları merkezinde üretilmiş bilgi kırıntıları da modern insanın anlam arayışlarına cevap vermemektedir. Modern dünyanın sorunlarını domine etmek şöyle dursun cevap dahi 
verememektedir. Russell'ın çarpıcı ifadesiyle özetleyecek olursak, modern insan artık bilim dururken yaşam olaylarını izah etmekte "tanrı teorisi"ne ihtiyaç duymamaktadır. (Russell 1996: 84-89)

Algısal ve deneysel olarak “doğrulanabilen” seküler bir dili, hayatın bütün alanlarını kapsayacak şekilde genişleten pozitivist paradigma, dini iddiaları olgusal olarak doğrulanması mümkün olmadığı için "doğrulanamayan” ve dolayısıyla rasyonelleştirilmesi mümkün olmayanlar kategorisine yerleştirerek elemiştir. Aslında kurtarıcı dinlerin mutlakiyetçi pratiklerinden ve dogmatik yaklaşımından insanlığı kurtarmak arzusuyla yanıp tutuşan pozitivizm, kendisi de nihayetinde bir tür eskatolojiye; bir kurtuluş dinine dönüşmüş haldedir. Zira teolojik ve metafizik bilgiye nazaran daha üstün olduğunu düşündüğü bilimi kutsayıp mutlaklaştırmış ve kurtarıcı bir Mesih gibi pazarlamaktadır. Yegâne kurtuluş adresi olarak bilimi göstermekte ve adeta insanlığ 1 bilim dinine tam bir imana ve mutlak bir itaate çağırmaktadır ve tıpkı dinler gibi bu tutumunda hiçbir sakınca da görmemektedir. (Gusdorf 2000: 17)

Pozitivizmin arka planında, aslında Batı aklının en büyük takıntısı olan somut düşkünlüğü yatmaktadır. Tanrı'yı dahi somuta indirgemeksizin idrak edemeyen (İkbal 2015: 78) bir düşünce formunun, insanı ete kemiğe ve bilgiyi de tamamen olgusal olanın bilgisine indirgemesinden daha doğal ne olabilir? Nitekim Paul Hazard'ın yukarıda da değinilen, çarpıcı metaforik deyişiyle, her şey mezura/cetvel ile ölçülebilmelidir. (Hazard 1973: 31) Pozitif bir usul ile ölçülmesi mümkün değilse rasyonel bir statüsü ya da bilgisel bir değeri düşünülemez. Doğa bilimleri ve teknoloji alanında yakalanan başarı nedeniyle insani ve sosyal bilimlere de aynı usul ve yöntemlerin uygulanması esas alınmıştır. Çoğunluk pozitivist camiaca itibar görmese de radikal versiyonlarınca insan sadece biyolojik bir canlı olarak hayvanlardan bir türdür; bir primat türü ya da pozitif mutasyona uğramış bir üst versiyonudur. İnsanı farklı görmenin elbette farklı sonuçları olacaktır ki, nitekim oldu ve bir ekonomi ve haz varlığına dönüşmüştür. Dünya matematikselleştirilerek parayla alınıp satılabilen arzu nesnelerine dönüştürülünce ve ekonomi hayatın merkezi haline gelince, modern öznenin de ekonomik bedeli belirli homo ekonomicus/ekonomik bir varlığa evrilmesi kaçınılmaz 
olmuştur. Artık peri masalları peşinde koşmak zorunda kalmayacağı için özgür ve mutlu olması beklenen modern özne, bu defa da somut pragmalar ve hazlar peşinde özgürlüğünü kaybetmek tehlikesiyle yüz yüzedir. Ölçülebilir bir hayat ve determinist bir dünya da beklenen mutluluğu getirmemiştir. Arzu nesnelerinin fotokopiyle çoğaltıldı̆̆ plastik hayatlar, her mutluluğun kolayca ve hızla tüketilmesine neden olmuştur. Önceki can sıkıntıları gitmiş olsa da yerini yenilerinin alması hiç gecikmemiştir. Öyle ki, hayatta kalma endişesinin baskın olduğu survivor modu aşarak varoluş moduna geçen ve varoluş sancıları ile yüzleşen insan, eski halini de arar olabilmektedir. Bilim ise insanın cevapsız yaşayamadığı doğum öncesi ve ölüm sonrası metaempirik hayata dair, nerden gelip nereye gidiyoruz türü büyük sorularına karşın insanı tamamen yalnız bırakmakta, cevap vermekten dahi imtina etmektedir. Kendisiyle çelişkiye düşmediği sürece cevap veremeyeceği de açıktır. Zira kendisini gayelilik ya da teleolojik akıl yerine "doğal", "olgusal" ve "gerçek" anlamında "pozitivite" ile sınırlamayı tercih eden Comte pozitivizminin temel karakteristiği (Özlem 2015: 50) 20. yüzyılın kaderini görüngü indirgemeciliği üzerinden okumaya ve domine etmeye çalışmıştır.

\section{Neo-pozitivizm}

Ancak çok geçmeden en sıkı pozitivistler dahi bu son derece muhafazakâr ve dogmatik pozitivist paradigmanın dar kalıplarına bağlı kalamamıştır. Ön kapıdan cesaret edemeseler de önce arka kapıyı hafifçe aralayarak mitolojinin girişine göz yummuşlardır. Zamanla dinler ve hatta daha uç mistik ve metafizik unsurlar dahi kimi arka kapıdan, kimi ön kapıdan içeri alınmaya başlanır olmuştur. Durumu en güzel örnekleyenlerden birisi, Robert E. Ornstein'dır; insan beyninin iki lobunun ayrı ayrı fonksiyonlarda uzmanlaşmış olmasına rağmen, birlikte ve uyumlu hareket etmedikçe, karşıtların birliği sağlanmadıkça sağlıklı çalışıyor sayılmadığı şeklindeki fizyolojik bulgudan (Ornstein 2003: 72) yola çıkarak, en az iki farklı bilinç ve rasyonalite türü bulunduğunu savlamaktadır. Birincisi analitik bilinç ki, rasyonel düşünen tarafımızdır, diğeri ise holistik bilinç; sezgisel düşünebilen tarafımızdır. "Bilimsel yaklaşımın yöntem anlayışına" ciddi eleştiriler yöneltmektedir. Doğası gereği metodolojik yaklaşım ve 
yöntemsel arındırmanın özden ciddi kayıplara neden olduğu gerçeğini, öncelikle açık yüreklilikle kabule davet etmektedir. Buğdayın saflaştırılması örneği üzerinden, genel olarak metodolojik yaklaşımı sorunsallaştırmaktadır; "Rafine edilmiş buğday asıl buğdayın sahip olduğu besleyici değerinden, özünden çok şey kaybetmiştir. Psikolojide biz de özün (bilincin) büyük bir kısmını, yöntemin arındırılması işleminde dışlarız." Gözleri görmeyen uzmanların fili incelemesi misali, her birinin tespiti hem doğru hem de yanlıştır. Aslında, toplanan bilgilerin her biri ayrı ayrı doğrudur ancak kısmen doğrudur. Fakat herkes sahip olduğu kısmi bilgiyi genelleştirdiği için yanlış bilgiye dönüştürmektedir. (Ornstein 2003: 25-26) İşte yöntemsel yaklaşım, bir şekilde zorunlu olarak, genellemecilik ve indirgemecilik yapmak suretiyle dinamik gerçekliği bir ana hapsederek tahrip etmektedir. Elde edebildiği 'az gerçekliği', 'nihai gerçeklik' olarak telakki etmekte ve ötekine de rasyonel şiddet yoluyla dayatmaktadır.

Sonuç olarak, "bireysel, analitik bir bilinçten, sezgisel yanlarımızı ĕgiterek meydana getirilen bütüncül biçime sıçrama" yoluyla "aklın her iki alanının bir sentezini yaratabiliriz." Sonra bireysel benliğimizde sağladığımız bu bütünlügüu, farklı beyinlerden müteşekkil "genişletilmiş benlik" olan insanlık düzeyinde bütünlüğü yakalar ve "hepimiz biriz" bilincine ulaşırız, aynı gaye için varız, aynı amaç için çalışıyoruz bilincine ulaşabiliriz. (Ornstein 2003: 174-176) Yogacıların metabolizma etkinliklerini kontrol edip değiştirebildikleri ve hatta kalplerini dahi durdurabildiklerine dair raporlar yüzlerce yıldır Batı'nın elindedir. $\mathrm{Bu}$ verileri, yöntem dışı olması nedeniyle, görmezden gelme ya da yok sayma yobazlığından derhal kurtulmalıyı. Bilimsel yöntemin kutsadığ “ "sıradan bilincin otomasyonu, yaşamı sürdürmek adına yaşantının zenginliklerini kaybettiğimiz bir değiş-tokuş”tan öte bir şey olmadığı görülmüştür artık. Oysa Doğu kültüründeki yoga ustalarının psikolojik çalışmaları, Batılı bilim adamlarınca saplantılı bir şekilde benimsenen yöntemsel sınırlardan çok öte beden ve bilincimizi yönetme imkanları bulunduğunu açıkça ispatlamaktadır. (Ornstein 2003: 183) Kitabın mütercimlerinden olan Psikiyatr Dr. Erol Göka’nın, “kelimenin tam anlamıyla pozitivisttir; somut ve ampirik kanttlar sever ve asla ilkelerinden vazgeçmez" (Ornstein 2003: 10) şeklinde tanıttığı Ornstein'ın Yeni Bir Psikoloji kitabının onuncu ve 
son bölümünün başlığı dahi, "Genişletilmiş İnsan Kavramı” oldukça manidar değil midir? Zira bu aşamadan sonra artık pozitivizmin dine kapı araladığı saptaması dahi anlamsız ve yetersiz kalmaktadır. Çünkü, kimi aşırılıklar içerme potansiyeli nedeniyle dinin merkezi çoğunluğu tarafından dahi ihtiyatla yaklaşılan kimi uç tasavvufi yorumlara doğru "geniş" kapılar araladığı görülmektedir. Doğu ve Uzak Doğu kültürlerine iade-i itibar eyleyen Ornstein, bütün insanlığın dini tecrübe ve psikoloji deneyimlerini dikkate alan "yeni bir sentez" ve "bütün evreni insan bedeninin ayrılmaz bir parçası kabul eden' “yeni bir psikoloji paradigması” önermektedir. (Ornstein 2003: 203) Böylesi devrimsel açılımların geleceği ne olabilir? Doğrusu her şeyi yeniden düşünme zamanı gelmiş olmalı!

\section{Sonuç}

Postmodern eleştiri döneminin aşılıp post-truth ya da trans hümanizm dönemine girildiğinin tartışıldığı şu günlerde, söz konusu paradigmatik değişimlerin güle oynaya benimsendiğini düşünmek fazla safdillik olacaktır. Oysa "ilerleme mitosu" "tüketim mitosu" vulgarizasyonu ile sonuçlanmış, Nietzsche'nin saptamasıyla, hayatın temel dinamiği olan değişimi görmezden gelerek, varlığı betimleyebilmekten öte düzene de sokabileceğine iman eden "yüceltilmiş gerçek dışı bir yanılgı"; statik bir hakikat anlayışı nedeniyle, tekelci bilim anlayışı da nihayetinde isyan ettiği kilisenin akıbetine sürüklenmiştir. (Küçükalp 2017:123) Anlam dünyası elinden alınan insanın mahkum edildiği ruh fakirliği ve kimlik bunalımı, otomatik hesaplara bağlanan mekanik ve monoton bir yaşamı sürdürmenin motivasyonunu tüketmiştir. İzafiyet ve Kuantum teorisiyle birlikte, bütün bunlar materyalist pozitivist "paradigmanın iflası"nı kaçınılmaz kılmıştır. Artık Batı bilimsel düşüncesini domine eden epistemik cemaatin temel motivasyonu olan indirgemeci-reductionist yaklaşım yerini bütüncül-holistik bir vizyona terk etmek zorunda kalmıştır. (Merdin 2013: 31) Böylesi bir arka plan ve özeleştirel bir sorgulama sonucu gerçekleşen geri adım, positivist rasyonalitenin bir zaafı olduğundan çok aslında gücü olarak da okunabilir. Zira tutarsızlığı artık açıkça ortaya konmuş bulunan din-bilim savaşını tetikleyen temel etken, mutlakiyetçi yorum 
ve uzlaşmaz bir tutumla adeta kendisini özdeşleştirilen kilisenin dini yanlış temsilinden başkası değildir. Ne var ki, kilisenin 'metafizik yabancılaşması'na karşın haklı bir isyan olarak yola çıkan bilimselci yaklaşım, tepkisel bir indirgemeci sapmayla materyalist kutba kayarak bir tür 'karşı yabancılaşma' sürecine sürüklenmiştir. Ancak gelinen noktada, kendini yenileme gücünü sergileyerek, kan tazelemek istemektedir. "Aklını kullanmaya cesaret et!" düsturuna dönüşü, kendi aleyhine de olsa, geç de olsa sergileyebilmektedir. Bu ise dinamik aklın ideolojik akılcılığa karşı zaferidir: tarihsel ve kültürel bir perspektifle sınırlılığını unutmamayı şiar edinen insanilik paradigmasını ihmal ya da ihlal eden; "insani" perspektifini "nihai" hakikat telakki eden dogmatik akılcılığın rasyonalist şiddet pratiklerine karşın eleştirel rasyonalitenin zaferidir.

Doğrusu insanı hayat karşısında en zayıf ve kırılgan kılan şey, anlam/gaye/hakikat yoksunluğu girdabına kapılmasıdır. Bireyin kolayca katlanması mümkün olmayan bir belirsizlik ve hiçlik duygusu, anlam ve değer yoksunluğudur. İnsanlık tarihi anlam/değer uğruna ölüme koşarak giden nice örnekler ile doludur. Anlamsızlığa düşüldüğünde ise olanca genişliğine rağmen koca evrenin daracık bir zindana dönüşüvermesini engelleyecek ikinci bir alternatif yoktur. Önce İstanbul Üniversitesi, akabinde ünlü Sorbonne Üniversitesi'nde olmak üzere, uzun y1llar felsefe tahsili yani filozof yönü pek bilinmeyen büyük şairimiz Necip Fazıl Kısakürek insanın bu trajedisini, büyüleyici bir sadelikle şöyle ifade etmektedir; "Alemin küfre göre başı hiç sonu hiç / İki hiçlik arasında varlık olur mu ki hiç!’ Kitaplara sığmayacak bir hakikati, iki satırlık bir beyte sı̆̆dırabilen sembolik dilin çok çağrışımlı ve zengin rasyonalitesi, aslında aynı zamanda, çok boyutlu ve çok katmanlı insan bütünlügünün indirgenemezliği ve tüketilemezliğinin en büyük delillerinden biridir. Anlam-değer şemalarımızı mündemiç hakikat modellerinin yüzyıllar içinde hızla eriyip eskidiği ve tüketildiği görünmekte olduğuna göre, insanın hayata tutunmasını mümkün kılan rasyonaliteyi sürekli güncel ve dinamik kılmak için eleştirel akıldan başka bir çare görünmemektedir. Zira ancak eleştirel akıl aklî kalabilmekte; dogmatikleştiğinde ise ister dini olsun ister seküler olsun, artık sönmüş bir ateşten farkı kalmamaktadır. Neopozitivist paradigmanın iki loblu/iki farklı bilinç açılımı; çifte rasyonalite ya da çifte 
bilgi türünün 'karşıtların birliği’ esasına dayalı çok boyutlu gerçeklik anlayışı, elbette ki çok daha renkli dünyalara kapılar aralayacaktır. Değerler dünyasından yoksun tek tipçi rasyonaliteyi esas alan bir bilim anlayışının dünyayı sürüklediği kültürel ve çevresel felaketler için de bir nefes olması muhtemeldir. Ayrıca dini rasyonalitenin kendine özgü gerçekliğinin yadsınamazlığının ortaya konmasıyla, nice entelektüel enerjileri heba eden çatışmalar son bulabilir, yeni sentezler ve yeni açılımlar mümkün olabilir. Bu sürecin kazanımlarından birisi de dinin insan için bir lüks değil, ihtiyaç olduğunun açıkça ortaya konulmuş olmasıdır. Tanrı öldürülünce(!) tanrısız kalınamadığı; aslı yadsındığında modern hurafeler ya da uyuşturucular ile ikamesi gerektiği ve ikamenin ise aslın yerini asla tutmadığı anlaşılmıştır. Nasıl yer çekimine karşı duyarsız kalmanın bir imkânı yoksa, aynı şekilde tanrısal içgüdünün grativitesine karşı durmanın imkânı olmadığı da görülmüştür.

Dini değerlere kap1 aralanmış görünse de acaba öze dönük hakkaniyetli bir yöneliş midir, yoksa Heideggerce sorgulayacak olursak, "hesapçı rasyonalite"nin boğucu ve bunaltıcı vizyonuna, bir maneviyat protezi ikamesi arayışı mıdır? Materyalist paradigmanın iflası denecek özde bir değişim midir söz konusu olan, yoksa özde görünümlü sözde bir değişim midir? Samimiyet testi yapabilmenin bir yolu var elbette; tanrı yerine ne konulduğuna bakmak! Zira eğer tabiri caizse, sazın bam teli misali, dini düşüncenin de bam teli tanrı anlayışıdır. Neo-pozitivist dönemecin nirengi noktası da burasıdır aslında. İster toplum ister devlet densin, sonuç fark etmez, artık yeni tanrı bilimiyle, teknolojisiyle hatta son açılım ile eklemlenen yeni metafiziğiyle modern Devlet'tir. Nitekim Albert Camus ve Hegel'e göre modern devlet geleneksel devlet değildir artık, yeni işlevleriyle o bir “tanrı devlet”tir. Devlet toplumun yerine geçer ve tanrılaşır. Tanrı artık İsa'da değil, devlette tecessüm etmektedir. (Celilzade 2017: 44) Aynı şekilde Foucault'un tanrıya öykünen iktidar modeli olarak Panoptikon (her şeyi gören göz) kavramlaştırması ve Jung'un da modern dönemde devletin Tanrı'ya, devlete 
itaatin tapınma ritüellerine dönüşmesi ve itaat etmeyenlerin şeytanlaştırılmasına dair nosyon ve analizleri bilinmektedir. ${ }^{1}$

Kur'an'ın neden gerçek dinin yalnızca Allah'a has ve mahsus kılınması idealinden daha aşağısına rıza göstermediğini, bu bağlamda tekrar düşünmek gerekir. Tanrısal yetkileri modern devlete devredildikten sonra, din ve metafiziğe tanınan sınırların genişletilmesinde bir sakınca görmeyen yeni bir strateji midir yoksa gerçeklemekte olan? Zira modern rasyonalitenin özü metafiziğe bir sınır çizme ve bu sınırlar dışında yetkisiz sayma paradigmasına dayanmaktadır aslında. Tüm dini ve metafizik rasyonalitelere kucak açan versiyonu ile “ilahî pozitivizm”(!) tüm klasik ve kadim değerleri kapsayana dek, kendini güncellemeye devam edecek görünmektedir. Umarız, yalnızca pragmatik pratiklerde kalmaz bu hakikat mayası ve varlığı indirgemeci ideolojik gözlüklerle değil hakikati üzere idraki esas alan yarınlara gebe kalır. Her parmak ucunda, her göz izindeki imzada kendini tescilleyen biriciklik yasası mucibince, aslında her hakikat özünde biricik ve tüketilemez bir farklılık taşımaktadır. Böylesi eşsiz renklilik ve zenginlik ontolojisi üzerine kurulu bir hayatı ve göz bebeği mesabesindeki insanı, ruhsal ve manevi katmanlarından soyutlayarak, kolunu kanadını kırarak, tek bir boyuta indirgemek suretiyle tüketmenin imkanı olmadığı açıktır. O halde, bilime düşen kendisini bilimselcilik ideolojisinin dar kalıplarına düşmekten kurtaracak olan çoğulcu rasyonalite ve eleştirel akılcılığı esas alarak, içine düşebileceği rasyonel tahakküm ve entelektüel şiddet pratiklerinden içtenlikle uzaklaşmaktır. Farkı yargılamayı değil anlamayı esas almalıdır. Eğer maksat anlamaksa, ötekine bir güle yaklaşır gibi yaklaşmalı, hakikati incitmemelidir! Zira "hakikate giden yollar akıl kadar şiir, mit [kıssalar, efsaneler] ve Tanrısal vahiy”lerden de geçmektedir. (Guthrie 2011:9) Batı özelinde dahi, dini rasyonalitenin Aristo ve Newton fizikleri ile yüzyıllar boyunca uzlaşı içinde yaşaması, söz konusu çatışmanın yapısal değil konjonktürel olduğunun

${ }^{1}$ Bkz. Gizem Özdil, "Foucault Bağlamında İktidarın Görünmezliği ve "Panoptikon” ile "İktidarın Gözü" Göstergeleri, https://dergipark.org.tr/tr/download/article-file/138301; Carl Gustav Jung, Kitle Zihniyetinin Dengeleyicisi Olarak -Devlet Denetimindeki- Din, https://www.cafrande.org/kitlezihniyetinin-dengeleyicisi-olarak-devlet-denetimindeki-din-carl-gustav-jung/?amp; A. Yalçınkaya, (2012). “Tanrı: İktidar”, Sokrates'ten Jakobenlere Batı'da Siyasal Düşünceler, İstanbul: İletişi̧m Yayınları; Carl Schmitt (2005). Siyasi İlahiyat: Egemenlik Kuramı Üzerine Dört Bölüm, çev. Emre Zeybekoğlu, Ankara: Dost Yayınları. 
apaçık kanıtıdır. İslam uygarlıkları tarihinde ise ilerleme ve medeniyet kurucu dinamiklerin neredeyse tamamı dini referanslıdır. Yeni bir gerçekliğin tezahürü ile değişen dinamiklerin kazananı aslında ne şudur ne budur ne pozitivizm ne de dindir, kazanan insanlıktır. Çünkü, bilimsiz dinin hurafelere boğulmaktan, dinsiz bilimin de insanı modern arzu nesnelerinin esiri kılmaktan kurtaramadığg bir kez daha görülmüştür. Hakeza asıl olan da budur; erdemlerin erdemi olan adaletin kazanmasıdır, adaletin yerini bulmasıdır. Zira erdemler arasında dahi olsa adalet sağlanamazsa kaos kaçınılmazdır. Eğer bir taraf kaybediyorsa, kazananın hangi taraf olduğunun bir önemi de yoktur; er ya da geç, her iki taraf da bu adaletsizlikten zarar görecektir. 


\section{KAYNAKÇA}

ALATLI, Alev (2019). "Amerika the Beautiful" Fesüphanallah! Nasihatname I, İstanbul: Turkuvaz Yayınları. Yayınları.

ARISTOTELES (1996). Metafizik, çev. Ahmet Arslan, İstanbul: Sosyal

AYDIN, Hüseyin (1984). Metafizikçi Olarak Nietzsche, Bursa: Uludă̆ Üniversitesi Yayınları.

BAYKAN, Fehmi (1996). Aydınlanma Üzerine Bir Derkenar, Ankara: Türkiye Diyanet Vakfi Yay.

CELİLZADE, Hayyam (2017). "Devlet Teorisine Iki Yaklaşım: Hegel ve Nurettin Topçu", Erişim Tarihi: 13.02.2020, (https://www.dusuncemektebi.com/m/23715/devlet-teorisine-iki-yaklasim-hegel-venurettintopcu)

ÇÜÇEN, A. Kadir (2012). Felsefeye Giriş, 7. basım, İstanbul: Sentez Yayıncılık. Yayınevi.

FREUD, Sigmund (1999). Dinin Kökenleri, çev. Selçuk Budak, Ankara: Öteki Yayınevi.

FREUD, Sigmund (2014). Totem Ve Tabu, çev. Hasan Can, Ankara: Tutku Yayınları.

GUSDORF, Georges (2000). Insan ve Tanrl, çev. Zeki Özcan, İstanbul: Alfa

GUTHRIE, W.K.C. (2011). Yunan Felsefe Tarihi, çev. Ergun Akça, İstanbul: Kabalcı Yayınevi.

HAZARD, Paul (1973). Batı Dünyasındaki Büyük Değişme, çev. Erol Güngör, İstanbul: Başbakanlık Kültür Müsteşarlığı Kültür Yayınları.

HEGEL, G. W. (2016). Din Felsefesi Dersleri, çev. D. N. Kadığlu, İstanbul: Pinhan Yayıncılık.

HENDRICKS, Scotty (2020). "Inançsızlı̆̆ın 5 Nedeni: Bertrand Russell Tanrı'ya Neden Inanamadı?", Erişim Tarihi: 06. 05.2020, (https://medium.com/inançsızlığın-5-nedeni-bertrand-russell-tanrı'ya-nedeninanamadi?) Kitabevi.

HUME, David (2016). Din Üstüne, 5. basım, çev. Mete Tunçay, Ankara: İmge

İKBAL, Muhammed (2015). İslamda Dini Düşüncenin Yeniden İnşası, İstanbul: Timaş Yayınları. Yayınları.

KALIN, İbrahim (2019). Ben, Öteki ve Ötesi, 20. basım, İstanbul: İnsan 
KALIN, İbrahim (2020). Perde ve Mânâ, İstanbul: İnsan Yayınları.

KANT, Immanuel (1963). "What is Enlightenment?", Ed. L. W. Beck, Kant: On History, pp. 154-161, New York: Macmillian Publishing Company.

KANT, Immanuel (1984). Seçilmiş Yazılar, çev. N. Bozkurt, İstanbul: Remzi Kitabevi Yayınları.

KÖKTAŞ, Mümin (2017). "Aydınlanma, Hristiyanlık ve Deizm", Anadolu Üniversitesi Sosyal Bilimler Dergisi, 17/1, ss. 143-157, Eskişehir: Anadolu Üni. Sosyal Bilimler Enstitüsü.

KURT, Abdurrahman (2012). Din Sosyolojisi, İstanbul: Sentez Yayıncılık.

KÜÇÜKALP, Kasım (2017). Nietzsche ve Postmodernizm, 2. basım, İstanbul: Kibele Yayınları.

MERDİN, Sadettin (2013). Tanrıyı Arayan Fizik, İstanbul: Ozan Yayıncılık.

METE, Ali (2014). "Avrupa'da Köklü İslam Algisl: Martin Luther Örneği", Erişim Tarihi: 13.10. 2019, (https://perspektif.eu/2014/03/01/koklu-islam-algisi-martinluther-ornegi).

MORRIS, Brian (2004). Din Üzerine Antropolojik Incelemeler, çev. T. Atay, İstanbul: İmge Yay.

ORKUNOĞLU, Yener (2014). "Marx ve Din", Erişim Tarihi: 14.02.2020, (https://bilimvegelecek.com.tr/index.php/2014/12/01/marx-ve-din).

ORNSTEIN, Robert Evan (2003). Yeni Bir Psikoloji, 4. basım, çev. Erol Göka \& Feray Işı, İstanbul: İnsan yayınları.

ÖZLEM, Doğan. (2015). Evrensellik Mitosu. İstanbul: Notos Kitap.

PADEN, William E. (2008). Kutsalın Yorumu, çev. Abdurrahman Kurt, İstanbul: Sentez Yayıncılık.

RUSSELL, Bertrand (1996). Neden Hiristiyan Değilim, çev. Ender Gürol, İstanbul: İlke B. Yayım.

SCHOPENHAUER, Arthur (2013). Din Üzerine, 3 basım, çev. Ahmet Aydoğan, İstanbul: Say Yay.

SHARPE, Eric J. (1983). Understanding of Religion. London: Duckworth.

ŞİMŞEK, Nurdane (2015) "Ksenophnes'in Tanrı Anlayışı", Felsefe Arkivi, 43. Say1, 2015/II, ss. 65-81, İstanbul: İstanbul Üniversitesi Edebiyat Fakültesi Matbaası.

TASLAMAN, Caner (2016). Evrim Teorisi, Felsefe ve Tanrı, 20. basim, İstanbul: İstanbul Yay.

WOODS, Allen \& GRANT, Ted. (2018). Aklın Isyant: Marksist Felsefe ve Modern Bilim, çev. U. Demirsoy \& Ö. Gemici, İstanbul: Yordam Kitap Yayınları. 